\title{
Correction to: Conditional Action and Quantum Versions of Maxwell's Demon
}

\author{
Heinz-Jürgen Schmidt ${ }^{1}$ (iD
}

Published online: 8 October 2021

(c) The Author(s) 2021

\section{Correction to: Foundations of Physics (2020) 50:1480-1508 https://doi.org/10.1007/s10701-020-00387-9}

The article "Conditional Action and Quantum Versions of Maxwell's Demon", written by Heinz-Jurgen Schmidt, was originally published electronically on the publisher's internet portal on 30 September 2020 without open access. With the author(s)' decision to opt for Open Choice the copyright of the article changed on 17 September 2021 to (C) The Author(s) 2020 and the article is forthwith distributed under a Creative Commons Attribution 4.0 International License, which permits use, sharing, adaptation, distribution and reproduction in any medium or format, as long as you give appropriate credit to the original author(s) and the source, provide a link to the Creative Commons licence, and indicate if changes were made. The images or other third party material in this article are included in the article's Creative Commons licence, unless indicated otherwise in a credit line to the material. If material is not included in the article's Creative Commons licence and your intended use is not permitted by statutory regulation or exceeds the permitted use, you will need to obtain permission directly from the copyright holder. To view a copy of this licence, visit http://creativecommons.org/licenses/by/4.0.

The original article has been corrected.

Open Access This article is licensed under a Creative Commons Attribution 4.0 International License, which permits use, sharing, adaptation, distribution and reproduction in any medium or format, as long as you give appropriate credit to the original author(s) and the source, provide a link to the Creative Commons licence, and indicate if changes were made. The images or other third party material in this article are included in the article's Creative Commons licence, unless indicated otherwise in a credit line to the material. If material is not included in the article's Creative Commons licence and your intended use is not permitted by statutory regulation or exceeds the permitted use, you will need to obtain permission

The original article can be found online at https://doi.org/10.1007/s10701-020-00387-9.

Heinz-Jürgen Schmidt

hschmidt@uos.de

$1 \quad$ Fachbereich Physik, Universität Osnabrück, 49069 Osnabrück, Germany 
directly from the copyright holder. To view a copy of this licence, visit http://creativecommons.org/licen ses/by/4.0/.

Publisher's Note Springer Nature remains neutral with regard to jurisdictional claims in published maps and institutional affiliations. 